\title{
Granular cell tumor of the urinary bladder
}

\author{
Recep Bedir ${ }^{1}$, Rukiye Yılmaz ${ }^{1}$, Oğuzhan Özdemir², Hakkı Uzun³
}

Cite this article as: Bedir R, Y1lmaz R, Özdemir O, Uzun H. Granular cell tumor of the urinary bladder. Turk J Urol 2017; 43: 383-5

'Department of Pathology, Recep Tayyip Erdoğan University School of Medicine, Rize, Turkey

${ }^{2}$ Department of Radiology, Recep Tayyip Erdoğan University School of Medicine, Rize, Turkey

${ }^{3}$ Department of Urology, Recep Tayyip Erdoğan University School of Medicine, Rize, Turkey

Submitted:

16.05.2016

Accepted:

02.08.2016

Available Online Date: 03.08.2017

Correspondence:

Recep Bedir

E-mail:

bedirrecep@gmail.com

CCopyright 2017 by Turkish Association of Urology

Available online at www.turkishjournalofurology.com

\begin{abstract}
Granular cell tumors (GCTs) are extremely rare neoplasms of the bladder. In the literature, there are only a few reported cases. We present a GCT case with clinical, radiological, histomorphological, immünohistochemical findings and its differential diagnosis.
\end{abstract}

Keywords: Bladder; granular cell tumor; urinary system.

\section{Introduction}

Granular cell tumors (GCTs) are infrequently seen, and usually benign tumors which were first described by Abrikossoff, who considered them to be of muscular origin. Since then, however, the histogenesis of GCT has been a matter of serious controversy. This tumor most commonly arises from the head and neck region, especially the tongue. Bladder and other genitouninary organs are uncommon localizations for GCTs. Only 17 cases of GCTs of bladder origin have been reported to date, and, only 2 of them were malignant.

\section{Case presentation}

A 35-year-old woman was referred to our hospital because of painless, gross hematuria and voiding symptoms. The patient, with a history of kidney stones, appeared to be otherwise healthy. Blood tests, urinalysis, urine cultures, ultrasonography (USG), abdomen/pelvis magnetic resonance imaging (MRI), and cystoscopic examinations were performed. Urinalysis analysis demonstrated the presence of hematuria. Urine culture was negative for bacterial growth. MR, and contrastenhanced coronal computerized tomographic (CT) images showed an intense nodular mass with smooth margins localized on the left side of the bladder base with luminal protrusion
(Figures 1a and 1b). Diffusion-weighted MRI and Apparent Diffusion Coefficient (ADC) map revealed restricted diffusion of the lesion (Figures 1c and 1d). Cystoscopic examination revealed a nodular mass that was approximately $2 \mathrm{~cm}$ in diameter localized on the bladder neck, and protruding into the lumen. The tumor was removed by transurethral resection. Macroscopically, the neoplasm was $1.7 \times 1.5 \mathrm{~cm}$ in diamater, soft, and white-cream colored. Microscopically, there were cohesive groups of cells in lobules that were divided by fibrous septae. Neoplastic cells were polygonally shaped with small round nuclei and abundant granular cytoplasms (Figure 2a). There were no features of malignancy like necrosis, high mitotic activity, spindling of tumor cells or nuclei with large nucleoli in the resected tumor. There was no evidence of muscle invasion. Immunohistochemical staining revealed diffuse staining with S-100 protein (Figure 2b), neuron-specific enolase (NSE) (Figure 2c), and vimentin and synaptophysin. Staining for pan-cytokeratin (panCK), cytokeratin7 (CK7) and CD68 was negative. The Ki-67 proliferative index was low (1\%) (Figure 2d). These data supported the diagnosis of GCT.

Written informed consent was obtained from the patient before the aforementioned work was carried out. 

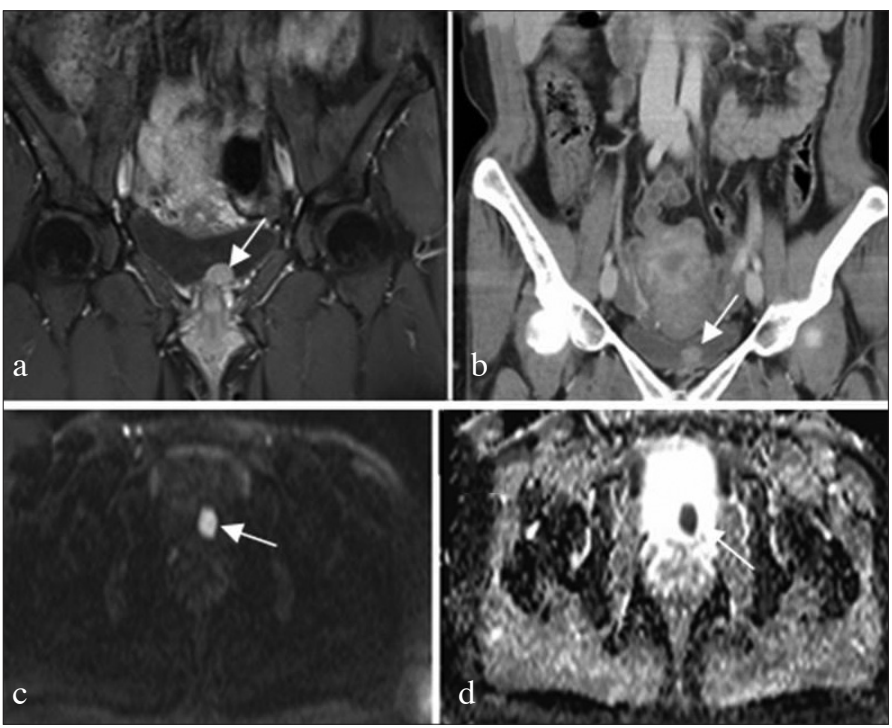

Figure 1. a-d. (a) contrast-enhanced coronal T2-weighted MR image, and (b) contrast-enhanced coronal CT image of a 35-year-old female patient showing a bulky nodular mass with smooth margins localized on the left side of the bladder base (white arrow shows luminal protrusion). (c, d) Diffusionweighted MR and ADC map reveal diffusion restriction of the lesion (white arrow)

\section{Discussion}

Granular cell tumors are rare, usually benign neoplasms that most frequently originate from the skin and oral cavity. ${ }^{[1]}$ However, GCTs in other locations (vulva, breast, larynx, esophagus, anal canal, extrahepatic bile ducts, gallbladder, heart, lacrimal gland, lung, parotid gland, tongue and thyroid) have also been reported. ${ }^{[2-7]}$ The bladder is a rare location. There are very few cases of granular cell tumor of the urinary bladder reported in the literature. ${ }^{[1-4]}$ GCTs show a mild predominance in females and are most often seen between the ages of 30-60 years. The majority of the congenital cases reported are located in the gingiva.

Granular cell tumor was firstly described by Abrikosoff in 1926 as myoloblastoma on the assumption that it was of myocyte origin. ${ }^{[7]}$ But today, based on immunohistochemical, histochemical and ultrastructural analyses, GCTs are believed to have a neural origin. ${ }^{[8,9]}$

Morphologically, GCTs of all anatomic sites share the same histological findings as polygonal cells with abundant granular cytoplasm containing fine eosinophilic granules and scattered larger droplets. ${ }^{[2,10]}$ There are 17 reported cases of GCTs of the urinary bladder in the literature, and only 2 of them are malignant. ${ }^{[3,11]}$ It is important to make a differentiation between benign and malign granular cell tumors because of the
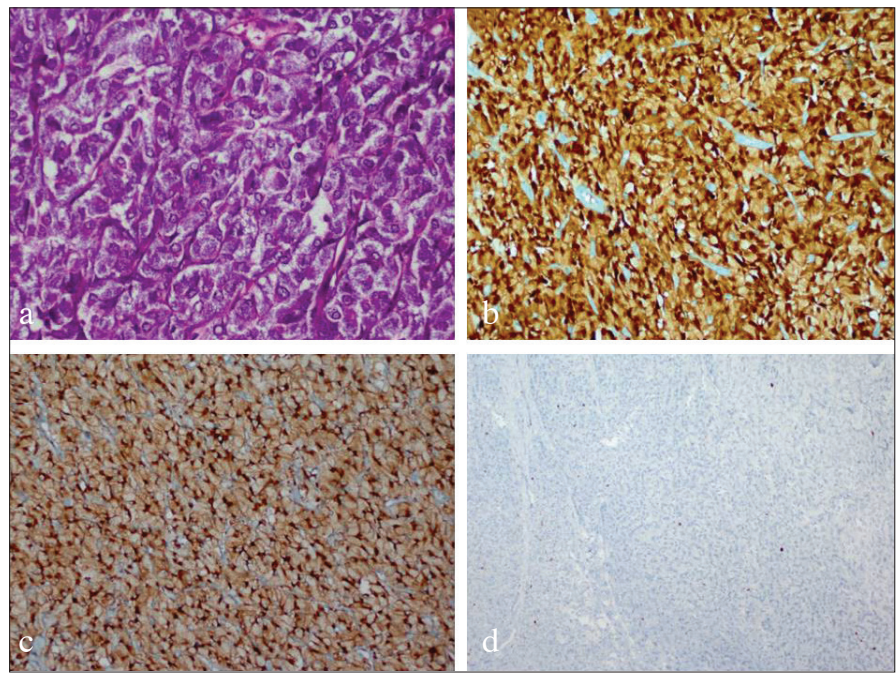

Figure 2. a-d. Tumor composed of cells with polygonally shaped small round nuclei and abundant granular cytoplasms (H\&Ex400) (a). strongly positive GCT for S-100 (x200) (b). strongly positive GCT for NSE (x200) (c). Decreased Ki-67 proliferation index (x200) (d)

difference in their treatment protocols. Malingnancy features in GCT include necrosis, high mitotic activity, high Ki-67 index, spindling tumor cells, vesicles with large nucleoli and muscle invasion. These features in combination are useful for diagnosis.$^{[12]}$ Lack of these morphological findings helped us to exclude malignancy in our case.

Immunohistochemistry is very useful for the differentiation of GCT from the more common benign and malignant lesions like malakoplakia, carcinomas or sarcomas. Tumor cells are stained positively with S-100 protein, calretinin, the alpha subunit of inhibin, laminin, HLA-DR, various myelin proteins, neuronspecific enolase (NSE), CD56, epithelial membrane antigen (EMA), synaptophysin, CD68 and SOX10. The tumor cells are negative for epitelial markers. ${ }^{[7,13,14]}$

Because of the predominantly benign course of the GCTs, conservative surgical treatment by transurethral resection taking care to leave clear surgical margins is sufficient and more radical resections are not required..$^{[1-3,15]}$

In conclusion, GCT is an unusual lesion of the urinary bladder. To differentiate this benign tumor from more common urothelial lesions, careful histomorphological examination and appropriate immunohistochemical studies are necessary. Immunohistochemistry is very helpful for diagnosis. Although the bladder is a rare location for GCT, it should be considered in the differential diagnosis of nodular lesions of the bladder, and clinicians and pathologists need to be aware of GCT in the differential diagnosis. 
Informed Consent: Written informed consent was obtained from patient who participated in this case.

Peer-review: Externally peer-reviewed.

Author Contributions: Concept - R.B.; Design - R.B., R.Y.; Supervision - R.B.; Resources - R.B., RY., O.Ö.; Materials - R.B., R.Y., O.Ö., H.U.; Data Collection and/or Processing - R.B., R.Y.; Analysis and/or Interpretation - R.B., R.Y., O.Ö., H.U.; Literature Search - R.B., R.Y.; Writing Manuscript - R.B., R.Y.; Critical Review - R.B., R.Y.

Conflict of Interest: No conflict of interest was declared by the authors.

Financial Disclosure: The authors declared that this study has received no financial support.

\section{References}

1. Kang HW, Kim YW, Ha YS, Min YK, Kim WT, Kim YJ, et al. Granular cell tumor of the urinary bladder. Korean J Urol 2010;51:291-3. [CrossRef]

2. Knief J, Becker JU, Kreipe HH, Kuczyk MA, Gabuev A, von Klot C. Granular cell tumour of the urinary bladder. Rare Tumors 2012;4:e22. [CrossRef]

3. Abbas F, Memon A, Siddiqui T, Abbas F, Memon A, Siddiqui T. Granular cell tumours of the urinary bladder. World J Surg Oncol 2007;5:33. [CrossRef]

4. Yoshida T, Hirai S, Horii Y, Yamauchi T. Granular cell tumour of the urinary bladder. Int J Urol 2001;8:29-31. [CrossRef]

5. Rosai J. Rosai and Ackerman's Surgical Pathology. 10th edition. Mosby: Elsevier; 2011. pp 812,1729,601,989,2474,330,398,838,5 37.
6. Bedir R, Yilmaz R, Sehitoglu I, Ozgur A. Coexistence of granular cell tumor with squamous cell carcinoma on the tongue: a case report. Iran J Otorhinolaryngol 2015;27:69-74.

7. Abrikossof A. Ueber Myome ausgehened von der quergestreiften willkuerlichen Muskulatur. Virchows Arch (Patho Anat) 1926;260:215-7.

8. Mouradian JA, Coleman JW, McGovern JH, Gray GF. Granular cell tumor (Myoblastoma) of the bladder. J Urol 1974;112:343-45. [CrossRef]

9. Sobel HJ, Schwarz R, Marquet R. Light and electron microscope study of the origin of granular cell myoblastoma. J Pathol 1973;109:101-11. [CrossRef]

10. Miettinen M, Lehtonen E, Lehtola H, Ekblom P, Lehto VP, Virtanen I. Histogenesis of granular cell tumour-an immunohistochemical and ultrastructural study. J Pathol 1984;142:221-9. [CrossRef]

11. Ravich A, Stout AP, Ravich RA. Malignant granular cell myoblastoma involving the urinary bladder. Ann Surg 1945;121:361-72. [CrossRef]

12. Fanburg-Smith JC, Meis-Kindblom JM, Fante R, Kindblom LG. Malignant granular cell tumor of soft tissue: diagnostic criteria and clinicopathologic correlation. Am J Surg Pathol 1998;22:779-94. [CrossRef]

13. Na JI, Kim HJ, Jung JJ, Kim Y, Kim SS, Lee JH, et al. Granular cell tumours of the colorectum: histopathological and immunohistochemical evaluation of 30 cases. Histopathology 2014;65:76474. [CrossRef]

14. Gurzu S, Ciortea D, Tamasi A, Golea M, Bodi A, Sahlean DI, et al. The immunohistochemical profile of granular cell (Abrikossoff) tumor suggests an endomesenchymal origin. Arch Dermatol Res 2015;307:151-7. [CrossRef]

15. Kondo T, Kajimoto S, Okuda H, Toma H, Tanabe K. A case of granular cell tumor of the bladder successfully managed with extraperitoneal laparoscopic surgery. Int J Urol 2006;13:827-8. [CrossRef] 